\title{
Evaluation of Human Resource Management Practices on the Productivity and Performance of Transport Organizations in Nigeria...
}

\author{
Chinebuli C. Uzondu \\ Department of Transport Management Technology, Federal University of Technology Owerri
}

\begin{abstract}
The objective of any organization or firm is to achieve higher productivity. The concept of Human Resources within organizations is very vital in the management and survival of any organization; this is because their performance is influenced by a set of human resource practices. The main focus of this study is to determine if human resources management practices (Human resources (HR) Planning, training and development) affect productivity and performance of Transport Organizations. The human resource management practices or HRM practices have to be addressed in this position, in order to examine productivity and performance of the organization. In analyzing the data, both descriptive and inferential statistics were used. A total of 75 questionnaires was distributed out of which 60 was returned. Result of analysis showed that training and development enhances productivity of transport organizations and also adequate human resources planning promotes employee productivity and organizational performance. It is therefore recommended that all level of employees receive adequate training and proper human resource planning should be in place to promote productivity and performance of the Transport industry in Nigeria.
\end{abstract}

Keywords: Human Resource Management Practice, Human Resource planning, Productivity, Performance, Training and Development.

\section{Introduction}

For any organization to achieve the aim of good performance and productivity and to sustain its goals and objectives it must plan for human resources in any future period, the manager must know the type and volume of business for the period. From this point of view, one can determine the required number of employees at any point in time. Human resources development concept and methods as the case may be should be able to take its rightful place as a tool for development in the world, particularly in Nigeria .Proper Human Resource planning, training and development needs to be considered at a strategic level in the business, but also and perhaps more challenging, that employees (public/private) need to change their business strategies to focus on quality rather than cost.

Human resources Management(HRM) practices involves the process of establishing goals, procedures, methods ,rules and regulations necessary to guide the use of resources to achieve goals .It can influence firm performance through provision of organizational structures that encourage participation among employees and allow them to improve on how their jobs are performed. Use of effective HRM Practices (HR Planning, training and development) enhances organizational performance. It influences employee skills through the acquisition and development of a firm's human capital.

The transport industry plays an important role in the sustenance of socio-economic and political development of any nation. It is said that a nation that is immobile is not developed. This means that you need transport to move and the level of your transport development shows the level of development in a country.

Transport activities and associated services are central and highly relevant in any economy. The industry provides Employment and job opportunities, contributes to Industrial growth and development, revenue generation and institutional development in the country. Different departments adopt quick management strategies in order to remain positive, responsive, functional and competitive. (Okeudo, Uzondu and Onwuchekwa, 2010)

The focus of this research is to understand the operational concept while looking at the compatibility between HRM practices, productivity and performance of transport organizations in Nigerian. Also given the complex nature, dynamism and capital outlay required in this sector, there is need to put in place, from time to time adequate human resources capable of managing and sustaining the activities of the industry in such a manner that efficiency, sanity and increased productivity could be achieved.

\section{Statement Of Problems}

Despite the contribution of the transport sector to the economy, it still has its problems, the industry lacked requisite policy on Human Resources development; In addition to this, there is inadequate management 
development and planning, poor benefits and services, lack of safety condition and poor recruitment and selection procedure. According to Oyiseku and Gbadamosi (2008), another problematic issue relates to the lack of adequate integration of academic and practical training in transport education. This means that while most of the managers in the transport industry may possess the necessary academic training of management, they lack exposure to the real industry that would guarantee performance.

\section{Objective Of The Study}

This research is influenced by the complaint and suggestion of various transport experts and the researcher on the need to improve Human Resources management practices in the industry in order to make it more productive, Given that low productivity is often seen as a malady affecting performance of organizations and planning, training and development as one of the cures for the problem, the main focus of this study is therefore

1. To ascertain the effect of Human resources planning on productivity and performance of the transport industry.

2. To determine if Training and development enhances productivity of the transport industry.

\section{Statement Of Hypothesis}

The following hypotheses will be used in this study;

$\mathrm{H} 0_{1}$ Adequate Human Resources planning does not promote employee productivity and performance of the transport industry.

$\mathrm{HO}_{2}$ Training and development does not enhance productivity of the transport industry.

\section{Significance Of Study}

Transportation is very important in any economy. If managed effectively, it will go a long way in providing other necessary ingredients needed for the growth of the nation as a whole. This study will try to produce guidelines to the federal government and those professionals in the transport sector on the best policies to adopt in order to improve productivity and performance of the transport industry. Other organizations such as the Ministry of Transport, Nigeria Directorate of employment (NDE) etc will find this study relevant in adopting proactive policies that will bring a long lasting transformation in the transport industry which is a major source of revenue and employment in the country .It will also help those in academics who are policy markers and make room for more research and awareness in this area.

\section{Literature Review}

A number of factors contribute to the success of any organization, these include capital, equipment, and manpower etc.The most significant of these is the human factor, since it is the people that will put the other resources to good and effective use. The human factor remains the most sensitive and volatile of all factors in production and so requires proper handling to enable the other factors to be properly harnessed to the utmost advantage of the industry (C.V.Njoku, 2003). Every firm must plan and develop its manpower in order to increase productivity. Employees as individuals have their own set goals and want to reach the pinnacle of the career ladder and so they seek for recognition and achievement in the work place. Given this scenario, the right people must be recruited, trained and developed for the job.

Planning, training and human resources development are critical factors for economic growth, and the scope of the education provided to actors and practitioners in a particular industry (such as the Transport Industry) must enable them to meet current and future challenges. According to the World Bank report (1995) human resources development must seek to meet the demand for adoptable workers who can readily acquire new skills and must support the continued requirement of knowledge particularly as it affects the transport sector.

Knowledge usually begins with the realization that economics or institution are built not merely through the accumulation of physical, capital and human skill, but on a foundation of information, learning and adaptation which employees and employers must seek to attain regularly. Therefore, any policy that seeks to change the fortunes of the Nigerian transport industry or any other industry, must give priority to investment in human capital. This is to enable knowledge to be acquired and absorbed (through creating opportunities for learning).

The international labour organization (ILO), has observed that most countries of the world are yearning to improve their education and training (Grubb and Ryan 1999). The area of concern to most developed countries is greater investment in human resources which promises to produce the workforce for the $21^{\text {st }}$ century. The increasing global competition in the industry coupled with wide disparity in the current level of human resources development between the developed and developing countries make it imperative for all the stakeholders in the industry to develop their human capital. 
Training and development with proper human resources planning are a mixture of activities aimed at improving the performance of personnel in organizations for the attainment of continuous improvement in productivity.

\section{Human Resource Management Practices}

The impact of HRM practices on organizational performance is very important in the fields of HRM, industrial relations and industrial and organizational psychology (Boudreau 1991; Jones and Wright, 1992; kleiner, 1990). Recruiting procedures that provide a large pool of qualified applicants, with reliable and valid selection methods will have a substantial influence over the quality and type of skills new employees possess. Furthermore formal and informal training experience, coaching, management development can further influence employee development. Highly skilled employees may not even perform well if they are not motivated but HRM practices can affect employee motivation by encouraging them to work better. Bailey (1993) noted that the contribution of even a highly skilled and motivated workforce will be limited if jobs are structured or programmed in such a way that employees who know their work better than any one

else, do not have the opportunity to use their skills and abilities to design new and better ways of performing their roles.HRM practices has become a challenge in many organizations, every firm must plan and adopt personnel programs that should be fair to and void of favoritism in the organization. According to Hartel,Schmidt and Hayes(2002),HRM practices can generate increased knowledge,motivation,synerge and commitment of a firm's employees, resulting in a source of sustained competitive advantage for the firm.

In the organizations or firms, HRM practices acts as a mediator between HRM strategy and HRM outcome.

Sheppeck and Militello (2000) focus HRM strategy into four groups: employment skill and work policies, supportive environment, performance measurement and reinforcement and market organization whereas Guest (1997) divides it into three categories: differentiated on innovation, focus on quality and costreduction. However, there are many definitions in previous researches on HRM strategy, but all strategies are used to achieve the same organizational goal through HRM practices.Stavrou-Costea (2005) also argued that an effective HRM practice can be the main factor for the success of a firm. As supported by Lee and Lee (2007) HRM practices on business performance, namely training and development, teamwork, compensation/incentive, HR planning, performance appraisal, and employee security help improve firms' business performance including employee productivity, product quality and firm flexibility.

Abang, May- Chiun and Maw (2009) evaluated two components of HR practices namely, training and information technology and found out that it has direct impact on organizational performance. In addition,Zaini, Nilufar and Syed (2009) four HRM practices showed that training and development, team work,HR planning, and performance appraisal have positive and significant influence on business Performance.Hamdia and Phadett(2011) on the relationship between HRM practices, job satisfaction and turn over showed that HRM practices are positively and significantly correlated with job satisfaction and on the other hand negatively and significantly correlated with turnover and that the results of HRM practices(supervision, job training and pay practice)are strong predictors of turnover and productivity, and Huselid (1995) concluded from his research on the impact of Human Resource management practices on turnover ,productivity and corporate financial performance that Human Resource management practices can help to create a source of sustained competitive advantage, especially when they are aligned with a firm's competitive strategy ; and also that investments in high performance work practices are associated with lower employee turnover and greater productivity and corporate financial performance.

\section{Human Resources Plainning}

Human Resource planning is a process that identifies current and future human resources needs for an organization to achieve its goals. It should serve as a link between human resources management and the overall strategic plan of an organization. As defined by Bulla and Scott(1994) HR planning is the process of ensuring that the HR requirements of an organization are identified and plans are made for satisfying those requirements, it includes creating an employer brand, retention strategy, absence management strategy ,flexibility stategy,recruitment and selection strategy. These strategies and programmes are monitored and evaluated on a regular basis to ensure that they are moving the organization in the desired direction, including closing employee competency gaps and corrections are made. The purpose of HR planning is to ensure the best fit between employees and jobs while avoiding manpower shortages or surpluses. The Tennessee valley authority (TVA) defines it as the Systematic assessment of future manpower/workforce needs and the dissemination of the actions required for meeting those needs (Ripley 1995). 


\section{According to Gaurav Akrani (2011) steps in the HR planning process}

\section{Review of organization's objectives}

The human resource manager first studies the organization. Then he prepares a list of all the activities (jobs) that are required to achieve the objectives. He also does job analysis.

\section{Estimation of manpower resources}

The HR manager then estimates the manpower requirement of the organization. That is, he finds out how many people (manager and employers) will be required to do all the jobs in the organization. Estimation of manpower requirements must be made in terms of quality and quantity.

\section{Esimation of manpower supply}

The HR manager then estimates the manpower supply. That is, he finds out how many managers and employers are available in the organization.

\section{4. comparison of manpower}

The HR manager then compares the manpower requirements and manpower supply

\section{5. in case of no difference}

If there is no difference between the manpower requirements and the manpower supply, then the HR manger does not take any action. This is because manpower requirements are equal to the manpower supply.

\section{6. in case of difference}

If there is a difference between the manpower requirements and the manpower supply, the HR manager takes the following actions

\section{a. Manpower surplus}

If the manpower requirements are less than the manpower supply then there is a surplus. During manpower surplus, the HR manager takes the following actions:

Termination i.e. removal of staff, layoff and voluntary retirement.

\section{b.manpower shortage}

If the manpower requirements are greater than the manpower supply then there is manpower shortage. During manpower shortage, the HR manager takes the following actions: promotions, overtime, training to improve quality, hire staff from outside etc

\section{Motivation of manpower}

HRP also motivates the employers and managers by providing financial and non financial incentives.

\section{Monitoring manpower requirements}

The HR manager must continuously monitor the manpower requirements. This is because many employees and managers leave the organization by resignation; retirement etc. and new work force must take their place and fill the manpower gap. This helps in uninterruptible functioning of the organization.

\section{Training}

Training is one of the most important strategies for organizations to help employees gain proper Knowledge and skills needed to meet the environmental challenges (Goldstein and Gilliam, 1990; Rosow and Zager 1988). Employee training represents a significant expenditure for most organizations. Training too often is viewed tactically rather than strategically. Organizational leaders are often not clear about what they want from training and therefore fail to connect training with the overall organizational goals and strategy. To Daniels (2003) training should not be regarded as a luxury to be undertaken when time and budgets allow. Nor is it wise to think of training as remedial, as a matter of shoring up weak employees or fixing problems. In a successful program, the training unit acts not like a group of physicians who minister to organizational ills, but rather as an agent of change. Senior management should recognize that the training function has valuable intelligence about employees' core skills. The training unit, in a successful program, understands the organizations strategic direction and can design and implement a creative way of moving people in that direction. 
Many organizations have already shifted their thinking about the training function. They have seen for themselves that training is where skills are developed, attitudes are changed, ideas evolve and the organization is reinvented. In the course of learning the skills that will increase sales, build effective teams, improve quality, standards or meet a wide range of other objectives, employees create a new organizational culture. Also the need to look at business beyond the national boundaries and thinking strategically have forced many organizations to accord training and development due attention. Training according to Cole (1999) will be understood as any learning activity which is directed towards the acquisition of specific knowledge and skills for the purpose of an occupation or task. To Cole, the focus of training is the job or task. He gives examples of training needs as follows; the need to have efficiency and safety in the operation of particular machines or equipment, the need for an effective sales force, and the need for competent management in the organization. To Banjoko (1996), training is an organized procedure by which people learn knowledge and or skills for a definite purpose. That is it is a process for equipping the employees particularly the non- managerial employees with specific skills.In the view of Armstrong (1999), training is the systematic modification of behavior through learning which occurs as a result of education, instruction, development and planned experience.In a related work, Aina (1992) sees training as the acquisition of the technology which permits employee to perform according to standard. He then sees training as an experience, a discipline or a systematic action which causes people to acquire new skills and knowledge and predetermined behavior.Nwachukwu (1988) sees training as organization effort aimed at helping an employee to acquire basic skills required for the efficient execution of the functions for which he was hired. In his contribution Cascio (1989) sees training as consisting of planned programs designed to improve performance at the individual, group and/or organizational levels. To Cascio, improved performance in turn, implies that there have been measurable changes in knowledge, skills attitudes and/or social behaviour.Training in view of Decenzo and Robbins (1996) is a learning experience in that it seeks a relatively permanent change in an individual that will improve the ability to perform on the job. Decenzo and Robbins typically say training can involve the changing of skills, knowledge, attitudes, or behaviour. To them, it may mean changing what employees know, how they work, their attitudes toward their work, or their interaction with their coworkers or supervisor.Decenzo and Robbins see training as more present-day oriented, its focus is on individuals current jobs, enhancing those specific skills and abilities to immediately perform their jobs. In HRM practice, training is an important factor for productivity; higher productivity is observed in firms that report providing training (e.g. Tan \& Batra, 1995; Aw \& Tan, 1995).

A critical look at all the selected views on the concept of training revealed that they appear to be saying the same thing, what differs is the choice of words. One could then say that the fundamental aim of training is to help the organization achieve its purpose by adding value to its key resource that is the people it employs. Training means investing in people to enable them to perform better and to empower them to make the best use of their natural abilities for overall effectiveness and efficiency of an organization. An organization is seen to be effective and efficient if there is demonstrable increase in productivity.

\section{Development}

Lots of time training is confused with development, both are different in certain respects yet components of the same system. Development implies opportunities created to help employees grow. It is long term in nature as opposed to training which focus on current job. No person can actually develop another; all an organization can do is to create the atmosphere and opportunity for people to develop themselves .However Aina (1992) simply takes development as concerned with preparing the employees so that they can move with the organization as it develops, changes and grows.

In the view of Daft (1988), development refers to teaching managers and professionals the skills needed for both present and future jobs. Employee development according to Decenzo and Robbins (1996) by design is future-oriented and more concerned with education than employee training. By education we mean that employee development activities attempt to instill sound reasoning processes, to enhance one's ability to understand and interpret knowledge, rather than imparting a body of facts or teaching a specific set of motor skills. Decenzo and Robbins therefore see development as focusing more on the employee's personal growth. Successful employees prepared for positions of greater responsibility must have analytical, human, conceptual, and specialized skills. They should be able to think and understand. Training cannot overcome an individual's inability to understand cause-and-effect relationships, or to think logically. As a result, Decenzo and Robbins suggest that employee development be predominantly an education process rather than a training process.

One critical component of employee development considered by Decenzo and Robbins is that, all Employees, at no matter what level, can be developed. To them, historically, development was reserved for potential management personnel. Although it is critical for individuals to be trained in specific skills related to managing, like planning, organizing, leading, controlling, and decision making, time has taught us that these skills are also needed by non-management personnel. The use of work teams, reductions in supervisory roles allowing workers to participate in the goals of their jobs, and a greater emphasis on quality and customers, have 
changed the way developing employees is viewed. Accordingly, organizations now require new employee skills, knowledge and abilities.

A critical review of the all meanings given for development shows that the essence of it is that organizations want to avoid being caught badly without candidates for new jobs or without replacements for key people who died, retired or left for other jobs. Development involves learning what goes beyond today's job; it has a more long-term focus.

\section{Impact Of Human Resources Planning, Training And Development On Productivity And Performance Of Transport Organizations}

The main objective of setting up any firm is to make profit and to achieve this organizational goal; adequate human resource planning and development programmes should be put in place to enhance performance. Increasingly firms are considering the adoption of new work practices such as problem-solving teams, enhanced communication with workers, employment security, flexibility in job assignments, training workers for multiple jobs and greater reliance on incentive pay. Adoption of human resources planning, training and development produces substantially higher levels of productivity than do the more traditional approaches involving narrow job definitions, strict work rules and hourly pay.

Productivity is reaching the highest level of performance with the least expenditure of resources. Productivity is often seen as total output/total input. Thus the productivity of an employee is seen as the relationship between the employee input and output. Result of the study by Isiaka (2010) shows that productivity is really one of the driving forces for investment in training and development. Training and development helps employees to learn how to use the resources in an approved way that allows organizations to reach its desired goals, it has now become an everyday word. Productivity provides us with a way of looking at how efficiently production inputs are used in an economy. Since the Second World War, governments, politicians, academics and economists have all stressed the importance of productivity because of its relationship with the performance of any organization. Corporate management globally is concerned with productivity because it is regarded as a main indicator of efficiency when comparisons are made with competitors in world markets. Productivity is reaching the highest level of performance with the least expenditure of resources. Productivity is often seen as total output / total input.

The goal of HR planning is to boost organizational performance by ensuring that all departments are ideally staffed. It is used for budgeting purposes. Whenever an organization wants to grow and diversify, it requires an expanded workforce. This planning process is used to estimate how many additional workers are required.

It highlights the area where large numbers of employees need training and the HR department takes measures to arrange for the training and development sessions. Well trained employers are a boon to the organization; their productivity soars and organizational targets are met more rapidly

Through the HR planning process, organizations are able to gauge the net worth of all its department .a particular department might be bringing in thousands of naira but might be understaffed at the same time. If performance of HR planning in an organization is not good, then organization performance will be more difficult to achieve.

Training and development is one of the key HR functions and must be included in every organizations HR plan. Training is an Endeavour aimed to improve or develop additional competency or skills in an employee on the job one currently holds in order to increase the performance or productivity. Technically, training involves change in attitude, skills or knowledge of a person with the resultant improvement in the behaviour.

For training to be effective, it has to be a thorough need analysis and target at certain competencies, most important it is to be conducted in a learning atmosphere. Most organizations with high productivity levels have made training and development an integral part of their business culture because when you employ people and equip them with the right skills, the productivity level of that firm increases. Able People may grow to a point where they are ready for responsibilities beyond their initial assignment. When this happens, training and development become imperative. Training and development has grown concerned not only with helping individuals to adequately fill their positions, but also with helping the whole organizations and sub departments grow and develop. Training and development, though primarily concerned with people, since an organization can rarely secure people who are at the time of employment, total masters of their unique requirements, organizations need a good training and development programme. Training changes uninformed employees to informed employee; training changes unskilled or semiskilled workers in to employees who can do their assigned tasks in the way the organization wants them done, it turns them into workers who do things the right way. Consequently training and development has become one of the most critical aspects of human resource management effectiveness. No matter the way one looks at training and development, they help employees to learn how to use the resources in an approved fashion that allows the organization to reach its desired output. Training and development could then be seen as a mixture of activities aimed at improving the 
performance of personnel in organizations for the attainment of continuous improvement in productivity and organizational performance One of the potent factors militating against the good performance of employees is inadequate training. It is an established fact that no seriously minded organization can be staffed by people with expertise and potentials in the various discipline needed for its total functioning simply by recruitment. It is the systematic training and development of personnel on continuous basis that can harness the totality of human resources towards high productivity in the organization. That is the development of human resources continues to be of great importance to the well-being of contemporary organizations. According to American Society for Training and Development (ASTD) President and Chief Executive Officer, more than ever, business is investing in training.Training is usually aimed at solving significant problems as we are suppose to use it as a key requirement for ensuring that any training which takes place is based on proper analysis of its contribution to the effectiveness and efficiency of an organization. Training and development has been seen by scholars as an aid in adjusting to work environment which is designed to increase the capacity of individual or group in contributing to the attainment of the organizational goals.

\section{Introduction}

\section{Research Methodology}

This section presents the general procedure for carrying out the study. A description of the design and appropriate methodology adopted in carrying out the study is done. This work has carefully analyzed the operations of the present transport industry in Nigeria and compared it with what is obtainable in other countries, this is benchmarking. This part of the study covered research design, data selection, and study population, sources of data, data collection and data analysis procedures

\section{Data selection}

Primary and secondary data are utilized in this research. Primary data includes information from sampled population by means of oral interview, questionnaires etc within the transport sector of the economy.

Data selected for this study was from oral interview conducted within and outside chisco transport company and also from questionnaires distributed randomly to 75 respondents to which 60 responded. secondary data approaches includes information from textbook, existing literature, official documents, journals and magazines, internet publications, lecture notes etc

\section{Sampling Frame}

The sampling frame for this research, are the transport companies in Nigeria. The research made use of probability sampling for the selection of samples. Simple random sampling was used for this research. Random Sampling is that method of drawing a portion (or sample) of a population or universe so that each number of the population or universe has an equal chance of being selected. A sample drawn from random sampling is unbiased in the sense that no member of the population has any more chance of being selected than other members. Such a sample is unbiased and provides the best representative of the population.

\section{Population and sample}

Owing to the nature of the research, there was a need to select and a very efficient and effective transport company in Nigeria.chisco Transport Company is one of the major transport companies that has been in operation for a very long time in the country and has survived the unstable economic situation in Nigeria. 75 questionnaires were distributed among the senior staff, junior staff and some staff from the personnel department.

\section{Data Collection}

In carrying out this research, oral interviews were conducted, personal observation and findings on the functionality of management was done to find out how their staff is managed, for example their human resources management planning processes and job training and development programmes.This was found necessary so as to arrive at a conclusion about the feelings of the respondents concerning the organization and to ensure that results from the respondent are as unbiased as possible.

\section{Method of Data analysis}

In this stage a statistical modeling technique-Regression Method using product moment method will be used as the tool for the analysis which involves tables and calculations.

The Regression Method (product moment method) is represented as

$$
\mathrm{r}=\frac{\sum \mathrm{XY}-\mathrm{n}(\overline{\mathrm{X}})(\overline{\mathrm{Y}})}{-}
$$




$$
\sqrt{ }\left(\sum X^{2}-n(X)^{2}\right)\left(\sum Y^{2}-n(Y)^{2}\right)
$$

Where $\mathrm{n}=$ Number of items

$\sum=$ Sign of summation

$\mathrm{X}=$ Independent Variable

Y=Dependent variable

$$
\begin{aligned}
& \overline{\mathrm{X}}=\frac{\sum \mathrm{X}}{\mathrm{n}} \\
& \overline{\mathrm{Y}}=\sum \mathrm{Y}
\end{aligned}
$$

Note

$$
\mathrm{n}
$$

Standard Regression $=0 \geq r \geq 1$.

\section{Introduction}

\section{Data Presentation And Analysis}

Here, the results of the empirical analysis are reported and presented. The data collected from the questionnaire are summarized and presented on a table form; this is for easy analysis and presentation of results. The results of the analysis are interpreted with the hope of either accepting or rejecting the hypotheses of the study formulated earlier.

\section{DATA PRESENTATION}

This is the data collected from the 75 questionnaires sent ,out of which 60 were returned.

SOURCE: field work

\begin{tabular}{|l|l|l|}
\hline ITEM & YES & NO \\
\hline 1 & 60 & 0 \\
\hline 2 & 45 & 15 \\
\hline 3 & 40 & 20 \\
\hline 4 & 48 & 12 \\
\hline 5 & 22 & 38 \\
\hline 6 & 41 & 19 \\
\hline 7 & 25 & 35 \\
\hline 8 & 43 & 17 \\
\hline 9 & 28 & 32 \\
\hline 10 & 25 & 35 \\
\hline 11 & 28 & 32 \\
\hline 12 & 39 & 21 \\
\hline 13 & 33 & 27 \\
\hline 14 & 30 & 30 \\
\hline
\end{tabular}

The questionnaire has fourteen (14) questions with responses categorized as Yes or No. The responses were categorized in this way so as to achieve uniformity required to fit in the analysis. The total for each row is 60 which is the same with the number of respondents.

\section{Testing of hypothesis}

The data analyzed is in accordance with the hypothesis of the study and the hypothesis will either be accepted or rejected.

\section{HYPOTHESIS ONE (1)}

$\mathrm{H} 0_{1}$ Adequate Human Resources planning does not promote employee productivity and performance of the transport industry.

Question 4, 11,12and 13 from the questionnaire will be used for this analysis. 
Table two (2)

\begin{tabular}{|l|l|l|l|l|l|}
\hline ITEM & $\mathrm{X}$ & $\mathrm{Y}$ & $\mathrm{XY}$ & $\mathrm{X} 2$ & $\mathrm{Y} 2$ \\
\hline 4 & 48 & 12 & 576 & 2304 & 144 \\
\hline 11 & 28 & 32 & 896 & 784 & 1024 \\
\hline 12 & 39 & 21 & 819 & 1521 & 441 \\
\hline 13 & 33 & 27 & 891 & 1089 & 729 \\
\hline Total & 148 & 92 & 3182 & 5698 & 2338 \\
\hline
\end{tabular}

$\mathrm{n}=4$

-

$\mathrm{X}=\sum \mathrm{X}$

n

$\bar{X}=\frac{148}{4}=37$

$-$

$\mathrm{Y}=\sum \mathrm{Y}$

$\mathrm{n}$

$\bar{Y}=92$

$$
-=23
$$

4

$$
\begin{aligned}
& r=\frac{\sum X Y-n(\bar{X})(\bar{Y})}{\sqrt{\left.\sum X-n(\bar{X})^{2}\right)\left(\sum Y^{2}-n(\bar{Y})^{2}\right)}} \\
& r=\frac{3182-4(37)(23)}{\sqrt{\left(5698-4(37)^{2}\right)\left(2338-4(23)^{2}\right)}}
\end{aligned}
$$

$r=\quad 3182-3404$

$\sqrt{ }$ (5698-5476)(2338-2116)

$$
r=\frac{-222}{\sqrt{ }(222)(222)}
$$

$\mathrm{r}=-222$

$\sqrt{49284}$

$\mathrm{r}=-222$

$$
-=-1
$$

222

Conclusion: From the analysis above, we reject the hypothesis because the computed value of $r$ is negative. Therefore we accept the alternative

Adequate human resources planning promotes employee productivity and a firms Performance

HYPOTHESIS TWO (2)

$\mathrm{HO}_{2}$ Training and development does not enhance productivity of the transport industry.

The analysis is done with the following questions from the questionnaire: $1,2,3,5,6,7,8,9,10$. 


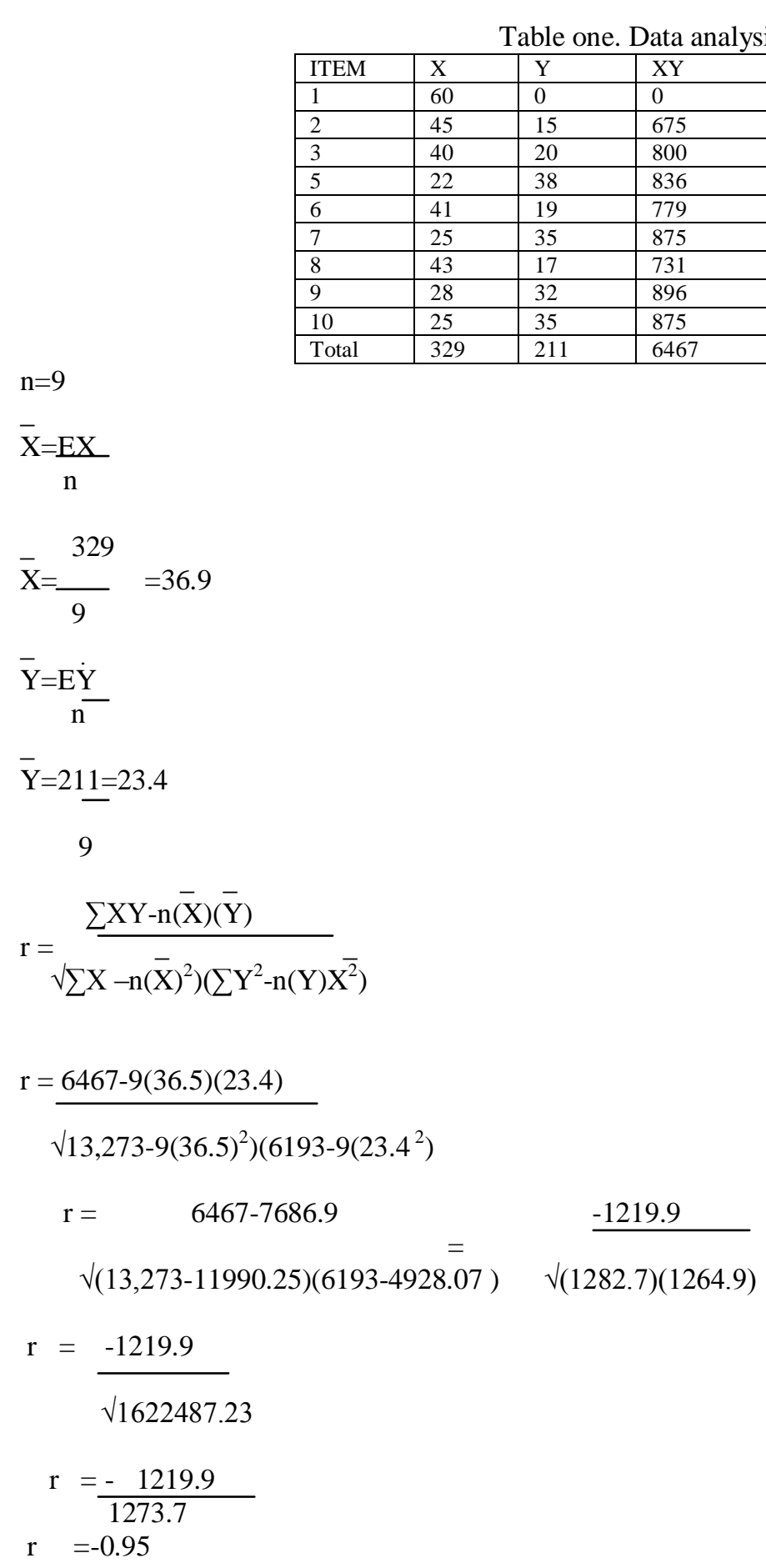

Conclusion: From the analysis above, we will reject the hypothesis because the computed value of $r$ is negative. Therefore we accept the alternative.

: Training and development enhances productivity of the transport organization

\section{Discussion}

This study adds to the growing literature on human resources management (HRM) by examining the relationship between HRM in practices (human resources planning, training and development) with productivity and performance in the transport industry. This study clearly explains three variables of HRM practices_ human resources planning, training and development. The organization seems to be more productive when there is proper and efficient human resource plan in place for the employees and training as on going learning for them in workplace (Bradley, Petrescu \& Simmons , 2004). The employees have tendency not to perform well when there is poor HR plan in the organization and without proper or poor training and development programmes 
(Poulston, 2008).Thus, it obviously shows that training and development enhances productivity in the transport sector and also adequate human resources planning promotes employee productivity and organization performance.

\section{Summary And Conclusion}

Human Resources Management practices in the Nigerian transport industry helps to improve the workforce at any particular time, thereby enhancing productivity and performance of the industry. It helps to analyze, forecast and project an organization's manpower requirements and also to optimize its usage of human resources. Based on the analysis, the following summary could be drawn;

Training and development enhances productivity of the transport industry.

Adequate Human Resources planning promotes employee productivity and performance of the transport industry

The quality of Human Resources of any organization determines the productivity and profitability of that organization. The result of the analysis clearly showed the relevance of Human Resources Management practices in the Nigerian Transport industry and Nigeria as a whole.

\section{Conclusion}

An organization's economic growth depends on productivity, if its productivity increases day by day, the company will run smoothly and attain the highest possible level of productivity to ensure sustainability of the organization. The success of an organization depends on effective human resource management practices and the competency of its Human Resources. As seen in the research, these human resource management practices (HR planning, training and development) have been shown to enhance productivity and performance of the transport industry. Any sensible transport organization must make proper use of these HRM practices to keep and develop the firm's employees as well as its operational performance. Training is concerned with the meeting between two inputs to organizational effectiveness, that is, people and technology. Training and development, with proper HR planning could then be seen as a mixture of activities aimed at improving the performance of personnel in organizations for the attainment of continuous improvement in productivity and also performance of that organization.

\section{Recommendation}

Based on the analysis of human resource management practices in the transport sector and considering the benefits and usefulness, the following recommendations are made:

It is an established fact that no serious minded organization can be staffed by people with expertise and potentials in the various disciplines needed for its total functioning simply by recruitment and selection. Management of transport organizations should provide opportunities for continued development and training of employees .Training is the best key to develop the employee's attitude, motivation and knowledge, therefore employees must be adequately trained and retrained to ensure that their knowledge, skill and competency remain useful and relevant. They should conduct on- the-job training programs to help improve on the available Human Resources and as a result enhance productivity and improve performance. This should be for all levels and categories of workers. They should be able to use the best techniques to analyze and forecast the present and future Human Resources of the industry, so as to get the best professionals for the job. There should be appraisal of the workers on a regular basis to monitor the performance of the workers.

\section{References}

[1]. Abang A. M., May-Chiun L. \& Maw K. L. (2009). Human Resource Practices and Organizational Performance. Incentives as Moderator. Journal of Academic Research in Economics, 1(2).

[2]. Aina, S. (1992). Personnel Management in Nigeria a Work-Centered Approach. Edition F. Communications, Ikeja P. 75

[3]. Aw, B. and Tan, H. (1995). Training, Technology and Firm-Level Productivity in Taiwan (China).Conference on Enterprise and Training Strategies and Productivity. World Bank, June 1995.

[4]. Amah, O. E. (2009). Job Satisfaction and Turnover Intention Relationship: The Moderating Effect of Job Role Centrality and Life Satisfaction. Research and Practice in Human Resource Management, 17(1), 24-35

[5]. Armstrong M. (1999). A handbook of Human Resource Management Practice, 7th Edition, London; Kogan Page Ltd pp.336\& 507.

[6]. Bailey, T., (1993) Discretionary effort and the organization of work: Employee participation and work reform since Hawthrone.working paper, Columbia University, Newyork.

[7]. Banjoko, S.A. (1996). Human Resource Management: An Expository Approach. Saban Publishers Lagos. P. 7

[8]. Bradley, S., Petrescu, A. and Simmons, R. (2004). The Impacts of Human Resource Management Practices and Pay Inequality on Workers Job Satisfaction. Paper presented at the Western Economic Association 79th Annual Conference Vancouver

[9]. Boudreau, J.W., (1991).Utility analysis in the Human Resources management decisions. In M.D. Dunnette and L.M.Hough (Eds).Handbook of industrial and organizational Psychology (2 $2^{\text {nd }}$ ed).vol 2:621-745.palo alto.CA: Consulting psychologists press.

[10]. Bulla,D.N. and Scott,P.M.(1994) Manpower requirements forecasting :a case example in( eds) D. Ward,T.P. Bechet and R Tripp.,HumanResource forecasting and modeling, the Human Resource planning society, New York

[11]. Cascio, W. F.and Silbey, V. (1979). Utility of Assessment Center as a Selection device, Journal of Applied Psychology 64, 107 ô 118 . 
[12]. Cole, G. A. (1999), Personnel Management, Theory and Practice, 4th Edition ELST, London p.211.

[13]. Daft, R. L. (1988). Management. The Dryden Press, a division of Holt, Rinehart and Winston Inc., p. 348

[14]. Daniels S. (2003). Employee training: a Strategic approach to better return on investment, Journal of Business Strategy, Volume 24 no. 5 pp. $39 \hat{o} 42$.

[15]. DeCenzo D. A. and Robbins S. (1996), Human Resource Management, 5th ed. Pp.237-252, New York: John Wiley Sons Inc.

[16]. Gaurav A. (2011) steps in the human resource planning process accessed 28/4/2011

[17]. Goldstein, I. L., Gilliam, P., (1990), Training System issues in the year 2000 American Psychologist, 45, 134 ô 43.

[18]. Guest, D. E. (1997). Human resource management and performance: a review and research agenda. The international Journal of Human Resource Management, 8(3), 263-276.47

[19]. Grubbs W.N. and Ryan P. (1999) The Roles of evalution for vocational education and training: Plain Talk on the field of dreams. Kogan page UK

[20]. Hamdia M and Phadett T(2011)Conceptual framework on the relationship between human resource management practices, job satisfaction, and turnover Journal of Economics and Behavioral Studies Vol. 2, No. 2, pp.41-49

[21]. Huselid M.A. (1995) The impact of HR Management practices on turnover, productivity and corporate financial performance. Academy of management Journal 1995, vol38; No 3,635-872.

[22]. Isiaka, S. B. (2002)A study of Correlation Between Training/Management Development and Corporate Productivity in the Banking Industry in Nigeria, An unpublished Ph.D. Proposal Department of Business Administration, University of Ilorin, Ilorin.

[23]. Jones, G.R and Wright, P.M. (1992) An Economic approach to conceptualizing the utility of Human Resources Management practices. In K.Rowland and G Ferris (EDs).Research in personnel and Human Management Vol 10:271-299.Greenwich (TJAI Press)

[24]. Kleiner, M.M (1990) The role of industrial relations in firm performance. In J.A.Fossum and J.Mattson (EDs).Employee and Labour relations: 4 23-43.washington.DC: BNA Press

[25]. Lee F-H. and Lee,F-Z.(2007)The relationships between HRM practices, leadership style, competitive strategy and business performance in Taiwanese steel industry,proceedings of the $13^{\text {th }}$ Asia pacific management conference,Melbourne,Australia,2007,953-971

[26]. Mali, P. (1978). Improving Total Productivity, New York, John Wiley and Sons, p. 48. Nwachukwu, C.C. (1987). Management: Theory and Practice, Onitsha, Africana-Fep Publishers Ltd, pp. 218- 241.

[27]. Okeudo G.N, Uzondu C.C.and Onwuchekwa C .U ; (2010) Evaluation of manpower planning and development of the Nigerian maritime indusrty.International journal of development studies volxiii/1.pp8-21

[28]. Oyesiku O.O. and Gbadamosi K.T.(2008) Port Administration and development in Nigeria. Ibadan HEBN Publishers

[29]. Poulston,J.(2008).Hospitality workplace problems and poor training: a close relationship. International journal of contemporary Hospitality management, 20(4), 412-427

[30]. Ripley, D.E. (1995):"How to determine future workforce needs", Jan.1995, p83

[31]. Rosow J. and Zager R. (1988)Training -the competitive edge; America institute Jossey-Bass publishers.

[32]. Sheppeck A.M. and Militello J. (2000) strategic Human Resource configurations and organizational performance. Human Resource Management vol39 (11) pp5-16

[33]. Stravrou-costea E. (2005)"the challenges of Human Resources Management towards organizational effectiveness: A comparative study in southern EU'Journal of European industrial training, vol 29(2), pp112-134

[34]. Tan, H.W. and Batra, G. (1995) Enterprise training in developing countries: overview of incidence, determinanats and productivity outcomes. World Bank occasional paper series, World Bank, Washington, D.C. World Bank report 1995

[35]. Zaini A., Nilufar A. and Syed S.A. (2009) The effect of Human Resources Management practices on Business performance among private companies in Malaysia, international journal of business and management,4(6),65-72

[36]. Oyesiku O.O. and Gbadamosi K.T.(2008) Port Administration and development in Nigeria. Ibadan HEBN Publishers

[37]. Poulston,J.(2008).Hospitality workplace problems and poor training: a close relationship. International journal of contemporary Hospitality management, 20(4), 412-427 